\title{
Sudan e-Government Master Plan and Transition to Smart Government 2016-2020 Comparison of Current Approaches
}

\author{
Yousif Eltahir Sharaf Eldin Ahmed \\ Sudan Academic of Science, Governmental University for Post Graduate studies, P. O. Box 86, Khartoum - Sudan
}

\begin{abstract}
Among the efforts of the National Information Center as a consultant to the Sudan Government, prepared the Sudan egovernment master plan In this context, the e-government master plan came after a study of the current situation for electronic services, taking into account the UN reports and the extent of progress in the field, in ICT collaboration with National IT Industry Promotion Agency (NIPA-Korea). Which came out twenty-five e-government projects in Sudan to be implemented within five years from the year 2016 - $2020 \mathrm{~m}$ with road map and the dependences between projects. The information was collected through interviews, Questionnaire and workshops, and It was used as a National Informatization Assessment Tool (NIAT) approved by the United Nations to analyze the information and extract the as is analysis, gap analysis and to be for the future vision
\end{abstract}

Keywords: Master Plan, NIPA, e-Government, NIAT

\section{Introduction}

e-Government is process that organizes the public administration by utilizing communication technologies pattern to transform public service delivery and management processes, government service delivery over the internet and other means of communication technologies without direct contact between citizen and civil servants will reduce endurances and increase efficiency.

e-Government Masterplan is based on the Sudan's TwentyFive Year National and Federal Strategy (2007-2031) and Five-Year Strategy, we proceed here to clarify the current situation of e-Government as the out of e-Government Masterplan. [1]

\section{Vision:}

A Society Satisfied with Government Services. [1]

\section{Mission:}

The utilization of ICTs to facilitate access of government services for beneficiaries through efficient and transparent appropriate channels to bring about sustainable development. [1]

General Objectives: [1]

- Facilitate, reduce and improve service delivery cost to beneficiaries.

- Provide accurate information to decision makers and researchers.

- Provide promising climate for investors.

- Raise the citizens' political participation level.

\section{Master plan Phases}

- The 2007 master plan has been built to be undertaken in three phases; before 2006 phase one, phase 2009-2011 known as phase two and phase 2012-2016 known as phase three.

- Phase One was a construction phase; it institutes related to ICT initiated during this period.
- Phase two included 21 various items between projects to acts and so on.

- Phase three included 8 various items too as well as planning.

\section{Project Overview}

The government of Sudan through the Ministry of Communication and Information Technology (MCIT) is in the process of establishing ICT collaboration with the Government of Republic of Korea (ROK) through NIPA (National IT Promotion Agency of ROK) under Korea's Ministry of Science and Future Planning.

The initial proposition is for NIPA to offer technical assistance in working with the ICT experts within Sudan to develop a comprehensive e-Government Master Plan Report for Sudan. This Master Plan report shall cover and integrate all sectors of the economy, and will conduct a feasibility study on the ICT sites as prioritized by both parties. So, this project has named

"Sudan e-Government Master Plan and Transition to Smart Government 2016-2020". [1]

Project background: [1]

In October 2014, Sudan Government officer who is NIC and NTC participated in ITU 2014 at Pusan in Korea. They discussed with NIPA about e-Government and Communication requirement. They signed MOU with NIPA. In March 2015, The Korean Embassy in Sudan received a Letter of Interest (LOI) document which included eGovernment requirements from NIC, which was forwarded to NIPA. NIPA recognized about needs from the Government of Sudan and discussed e-Government of Sudan with NIC. In June 2015, the initiation of the eGovernment Master Plan consultants was confirmed for the e-Government Master Plan. This project has been officially initiated by NIPA through MOU with NIC, support of Korean embassy in Sudan. 


\section{International Journal of Science and Research (IJSR) \\ ISSN (Online): 2319-7064}

Index Copernicus Value (2015): 78.96 | Impact Factor (2015): 6.391

Project Goal: [1]

In order to realize e-Government, there are several things to be considered such as informatization (digitization of resources to allow electronic transactions and seamless information exchange), services needed by people and businesses, and efficient way of delivering such services. Also, all the details such as the ICT infrastructure, legal/institutional efficacy of digitalized documents, status of public and private sector capacity, and formation of task force team (TFT), will be reviewed and incorporated in the master plan.

The main goal of this project is to achieve good governance and social and economic development by establishing effective, systematic, and productive e-Government. The final report will comprise of the following four points to achieve the goal.

- Establishing the vision, strategy and framework

- Selecting quick win projects and drawing a long term roadmap

Table 1: Details of Project Scope [1]

\begin{tabular}{|c|c|}
\hline Classification & Contents \\
\hline Target Ministries & 31 Ministries of Sudan (Including central and regional government organizations) \\
\hline Major Activites & $\begin{array}{l}\text { - } \quad \text { Meeting for Report: } 3 \text { Meetings (Kick-Off, Interim, and Final) } \\
\text { - Interview: Gathering information from } 10 \text { different ministries and on-site interviewxs } \\
\text { - } \quad \text { Survey participants: More than } 50 \text { officials, citizens and busineses } \\
\text { - Workshop: } 2 \text { Workshops (Workshops for evaluation of priority projects) - Explanation of Korea Case / } \\
\text { - Analysis and comparison of Sudan's status } \\
\text { - } \quad \text { Pata Acquisition and Analysis } \\
\end{array}$ \\
\hline Deliverables & $\begin{array}{ll}\text { - } & \text { As-Is Analysis Report: PEST Analysis, Onsite Survey Report, GAP Analysis } \\
\text { - } & \text { To-Be Stage Report: Strategy Development, To-Be Model Establishment } \\
\text { - } & \text { Project Implementation Report: Project priority assessment, road map establishment, and budget planning } \\
\text { - } & \text { Final Report }\end{array}$ \\
\hline
\end{tabular}

\section{Project Schedule: [1]}

The project plan is divided into four major phases. First is the "Preparation Phase," which is to prepare and make initiatives for this project. Second is the "Research \& Analysis Phase" which involves collecting and analyzing data such as government law/policy/regulation, informatization status, the requirement from citizens, business, and civil servants, benchmarking and others. Third is the "Strategy Development Establishment Phase," where visions and strategies are set up based on data analyzed in the second phase and where projects are selected, and their priorities are defined. The last phase is the "Implementation Strategy Phase" where the action plan for major projects defined in the third phaseis prepared.

The project duration is for six months, from the preparation phase to the final implementation plan establishment phase. Kick-off report will be written at the beginning of the project. An interim report will be prepared upon completion of the "As-Is Analysis," while executing the project. The final report will be prepared at the end of the project.
- Defining a governance framework to regulate and control e-Government initiatives

- Defining direction of restructuring legal framework

As the e-Government project is a government-wide initiative, their collective support, commitment and participation was absolutely essential for the success of the project. Prior to the current project, limited understanding of e-Government existed, although government entities like NIC had conducted workshops. Upon completion of the project, better understanding and realization of the benefits gained through e-Government is a subsequent goal that could impact the lives of citizens, public and private institutions of Sudan.

\section{Project Scope: [1]}

The project scope is as follows:
- Project kick-off meeting

2) As-Is Analysis

- Political Analysis

- Economic Analysis

- Social Analysis

- Technical Analysis

- Evaluating service status

- Evaluating informatization status

- Defining requirements

- Benchmarking

- Additional client needs assessment

- Interim reporting

3) To-Be Model Development

- Establishing vision and strategy for e-Government

- Proposing amendments or introduction to new laws or regulations

- Offering an e-Government governance structure

- Defining quick win projects

4) Implementation Strategy

- Scheduling action plan of project

- Final reporting

Entailments of each phase: [1]

1) Preparation

- Project Initiating

- Project team formation

- Aggregation of relevant materials

Volume 6 Issue 1, January 2017

www.ijsr.net

Licensed Under Creative Commons Attribution CC BY 


\section{International Journal of Science and Research (IJSR) \\ ISSN (Online): 2319-7064}

Index Copernicus Value (2015): 78.96 | Impact Factor (2015): 6.391

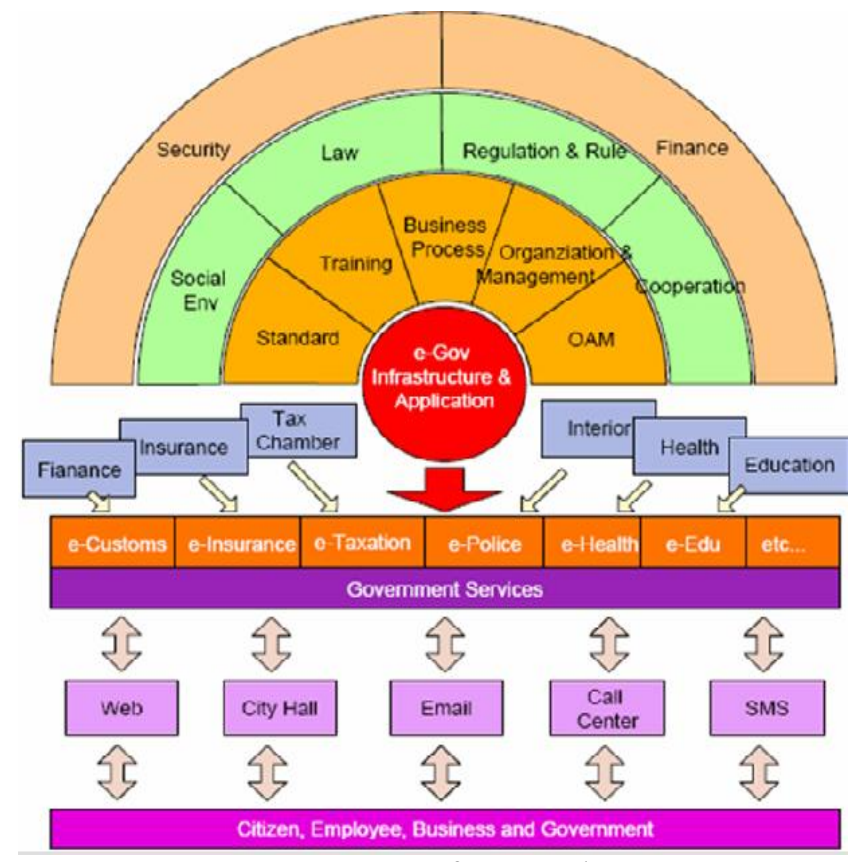

Figure 1: eGov framework [1]

\section{As Is Analysis}

Overview: [1]

The purpose of the As-Is analysis is to derive the directions for the Strategy Development based on the implications from each of the studies on the environment, informatization status and requirements, and comparison with best practices (benchmarking).

The environmental analysis provides general information, such as the geography and history; the PEST analysis looks into the policy, economic, social and technical environment of Sudan; the policy analysis analyzes the national policy.

Also the analysis of the ICT sector in Sudan provides an overview of the overall e-Government status, national and government ICT infrastructure.

The e-Government requirement analysis provides information on the needs of government officials, citizens and business corporations. The requirements were drawn from surveys and interviews which were conducted over a period of 2015.08.21 2015.09.01, and 2015.10.31 2015.11.05.

The level of informatization is evaluated with the National Informatization Assessment Tool (NIAT) which is an informatization level evaluation tool.

The abovementioned analyses are compared to the benchmark cases of the Korean government, which is currently recognized by the $\mathrm{UN}$ as ranking 1 st place in $\mathrm{UN}$ e-Government Maturity Index.

On the basis of the implications derived from each analysis, the Critical Success Factors (CSFs) were identified which will define the key improvement directions for Sudan's eGovernment. [1]

The analysis of the current situation according to the following areas: [1]
- Environment analysis

- General Information of Sudan

- Geography

- Lanndscape

- Policy Analysis

- National ICT Policy

- General Economics Analysis

- Forenign Direct Investment

- Exports and Imports

- Economics Growth

- Industry

- Agriculture

- Cotton

- Animal Production

- Manufacturing

- Petrolium

- Minerals and Other Products

- Services

- Business Environment and Competitiveness

- Social Environment Analysis

- Population

- Education

- Health

- Major Social Issues

- Social Infrastructure

- ICT Infrastructure

- Transport

- Road Infrastructure

- Railway Infrastructure

- Technical Environment Analysis

- Current Status of ICT Development

- Fixed/Mobile Communication

- Internet

- Supply Status of PCs

- Political Implications

- Economic Implications

- Social Implications

- Technological Implications

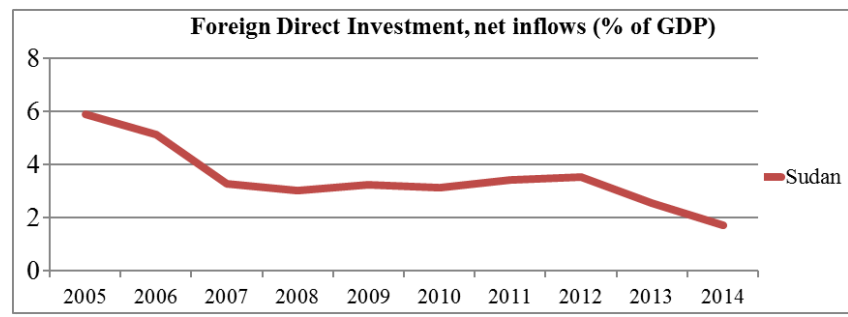

Figure 2: Foreign Direct Investment, Net Inflows (\% of GDP) [1]

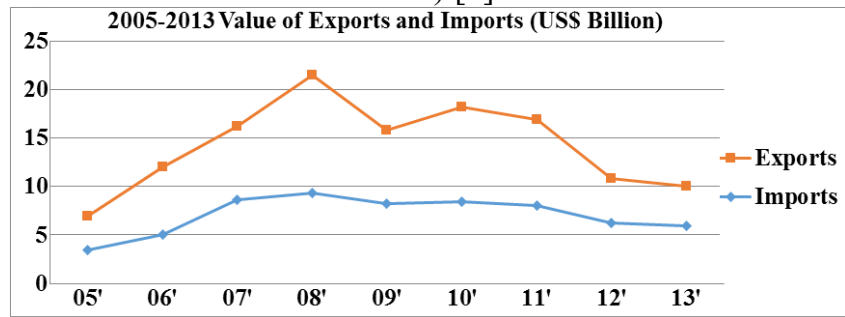

Figure 1: Value of Exports and Imports (2005 2013) [1]

\section{Volume 6 Issue 1, January 2017 www.ijsr.net}




\section{International Journal of Science and Research (IJSR) \\ ISSN (Online): 2319-7064}

Index Copernicus Value (2015): 78.96 | Impact Factor (2015): 6.391

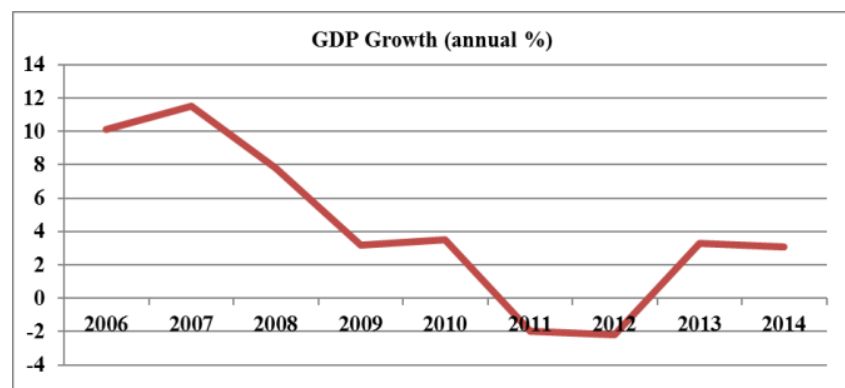

Figure 2: 2006-2014 GDP Growth (annual \%) [1]

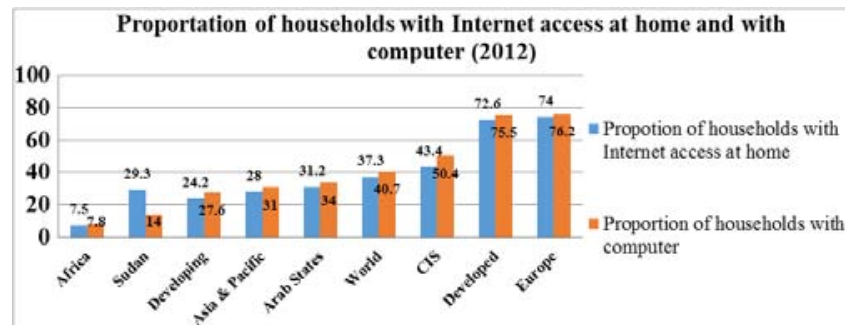

Figure 5: Penetration Rate of using Internet access at home with Computer (Rate: \%) [1]

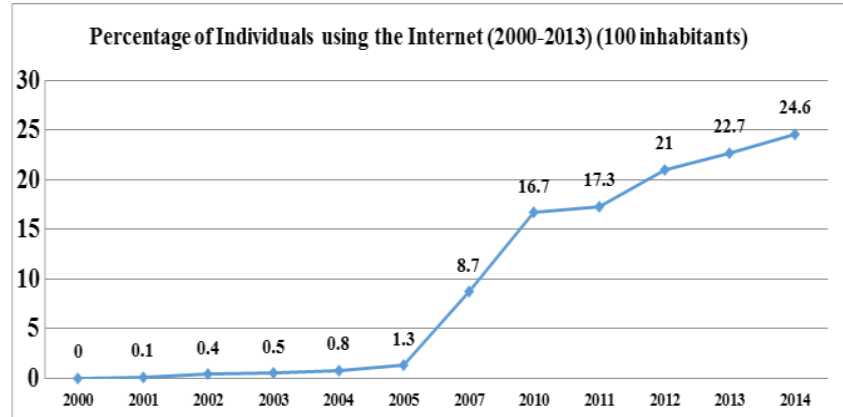

Figure 6: Penetration Rate of using Internet (Rate: per 100 Inhabitants) [1]

\section{Current Status of e-Government Analysis}

\section{e-Government Evaluation - UN e-Government Survey 2014}

The United Nations produces every two years the UN eGovernment Survey which assesses the development of eGovernment endeavors of all $193 \mathrm{UN}$ member states and identifies currents and future trends emerging from ICTs that can be leveraged by governments around the World. The survey defines the E-Government Development Index (EGDI), a composite measure of Online Service Index (OSI), Telecommunication Infrastructure Index (TII) and the Human Capital Index (HCI). The EGDI is important for countries in the early stages of e-Government in order to receive funding for e-Government initiatives. [1],[2]

- According to the UN e-Government Development Survey 2014, Sudan ranking improved from 164th in 2012 to 154th in 2014 and the country is classified under middle EGDI (Between 0.25 and 0.50 ), with only five countries in Africa (Tunisia, Mauritius, Egypt, Seychelles, Morocco) scoring a high EGDI

- The regional EGDI average in Africa is 0.2661, but Sudan scored 0.2606, which is lower than the average in Africa.

ICT Status of Departments [1]

Online Service (Front-End) Status
- View Point - Evaluating Front Office Service Level with UN Web Measurement Index

- Level Analysis and Core Indicators

Table 2: Level and Indicators [1]

\begin{tabular}{|c|c|}
\hline Level & Description and Indicators \\
\hline $\begin{array}{c}\text { Level } 1 \\
\text { Emerging }\end{array}$ & $\begin{array}{l}\text { - Provides policy, law, document information to } \\
\text { public via web (one-way) } \\
\text { - Supports link with other department, } \\
\text { organization and subsidiary } \\
\text { - Provides news and information list of } \\
\text { departments }\end{array}$ \\
\hline $\begin{array}{c}\text { Level } 2 \\
\text { Enhanced }\end{array}$ & $\begin{array}{l}\text { - Provides advanced one-way and basic two-way } \\
\text { service to public } \\
\text { - Provides downloadable forms, audio \& video } \\
\text { service and multilingual service } \\
\text { - Accepts civil administrative request via online }\end{array}$ \\
\hline \begin{tabular}{|c|} 
Level 3 \\
Transactional
\end{tabular} & $\begin{array}{l}\text { - Supports two-way service that allows citizen to } \\
\text { request government policy, program, law via } \\
\text { web } \\
\text { - Uses e-Certification system for online service } \\
\text { - Enables e-Voting, form downloading \& } \\
\text { uploading, e-Taxation } \\
\text { - Provides e-Transaction service with } \\
\text { government based on secured network }\end{array}$ \\
\hline $\begin{array}{c}\text { Level } 4 \\
\text { Connected }\end{array}$ & $\begin{array}{l}\text { - Active communication with public through } \\
\text { Web } 2.0 \text { and other communication tools } \\
\text { - Provides customized service based on citizen } \\
\text { life cycle } \\
\text { - Integration of departments } \\
\text { - Provides online environment so that citizen can } \\
\text { present their opinions on policy }\end{array}$ \\
\hline
\end{tabular}

- Front Office Service Level Analysis Result

- Analyzed front office service status of 39 government institutions based on UN

e-Government Evaluation Standard (2012)

- Most government institutions were Level 1 2

Table 3: Analysis Result

\begin{tabular}{|c|c|}
\hline Level & \multicolumn{1}{c|}{ Public Institutions } \\
\hline Level - & $\begin{array}{c}\text { - 19 institutions including Ministry of } \\
\text { Agriculture Irrigation, Ministry of Culture } \\
\text { and Information, and Ministry of Youth \& } \\
\text { Sports (SERVER DEFUALT PAGE, DOWN } \\
\text { FOR MAINTENANCE) }\end{array}$ \\
\hline $\begin{array}{c}\text { Level 1 } \\
\text { (Emerging) }\end{array}$ & $\begin{array}{c}-21 \text { institutions including Ministry of Defense, } \\
\text { Ministry of Industry etc. }\end{array}$ \\
\hline $\begin{array}{c}\text { Level 2 } \\
\text { (Enhanced) }\end{array}$ & $\begin{array}{c}\text { - 5institutions including Ministry of Higher } \\
\text { Education and Scientific Research, } \\
\text { Secretariat General of The Council of } \\
\text { Ministers etc. }\end{array}$ \\
\hline $\begin{array}{c}\text { Level 3 } \\
\text { (Transactional) }\end{array}$ & - None \\
\hline $\begin{array}{c}\text { Level 4 } \\
\text { Connected) }\end{array}$ & - None \\
\hline
\end{tabular}

System Status of Ministries: [1]

A survey was conducted on the different IT department institutions. The results of the survey show that though they have a purpose, the majority of projects have planned but not yet on the stage of implementation. 


\section{International Journal of Science and Research (IJSR) \\ ISSN (Online): 2319-7064}

Index Copernicus Value (2015): 78.96 | Impact Factor (2015): 6.391

- Since 2005, each government institution has been executing e-Government projects

- The main purposes of e-Government projects are for internal work improvement, online public services and encouraging citizen participation

- Most of projects are now in operation or in the development stage

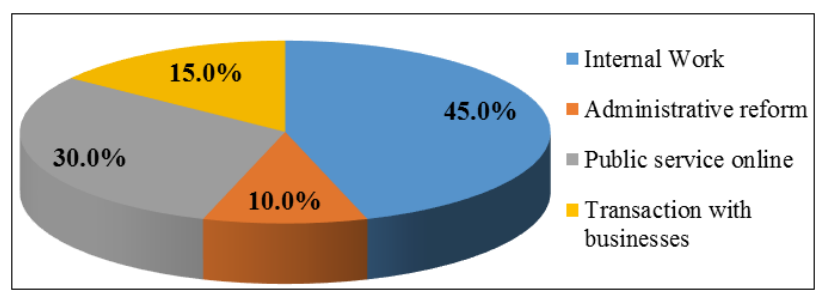

Figure 7: Main Purpose of e-Government Projects [1]

A user system is composed of local area network, website, $\mathrm{DB}$, search engine, etc.

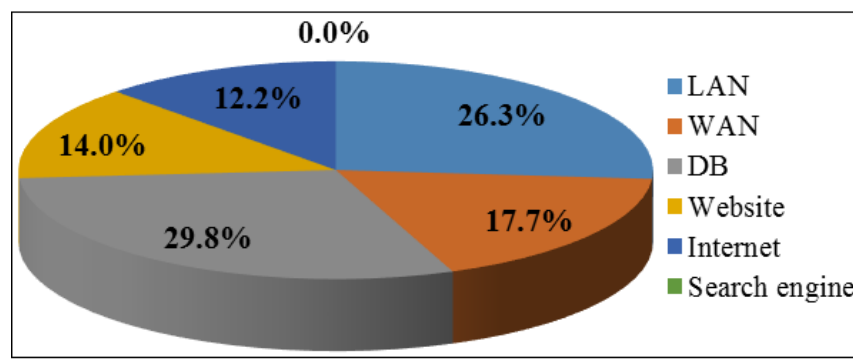

Figure 8: System Configuration [1]

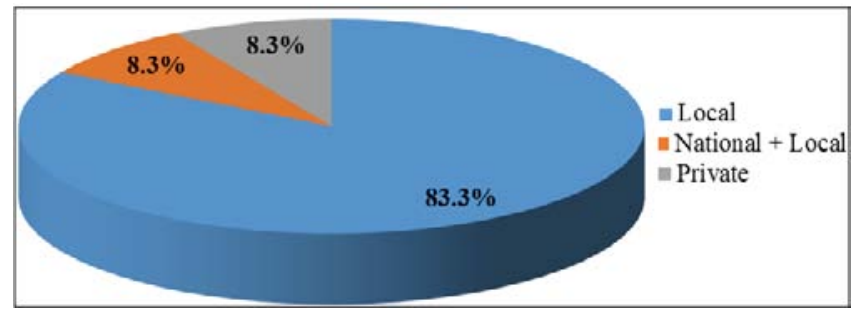

Figure 9: Project Funded [1]

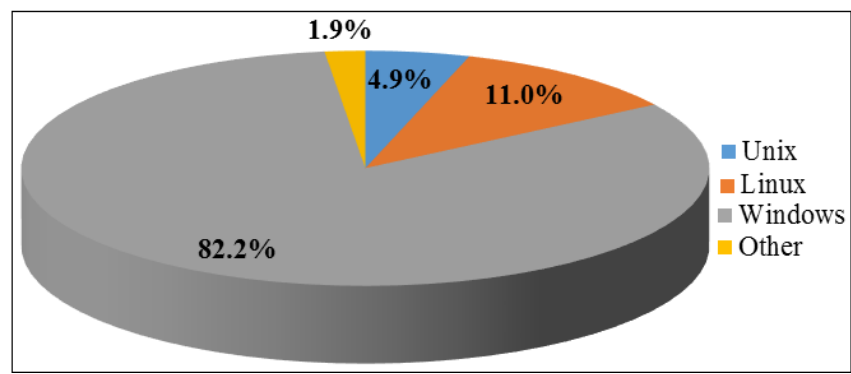

Figure 10: OS Configuration [1]

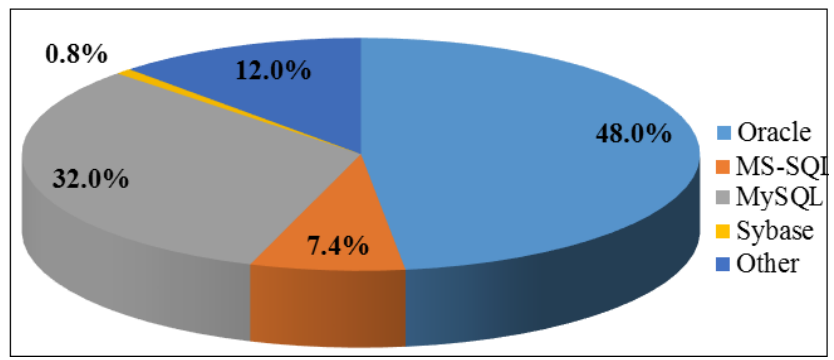

Figure 11: DBMS Configuration [1]
- Communication Channel

- Telephone, fax and e-mail are used as communication channels; other means such as video conferencing is also used

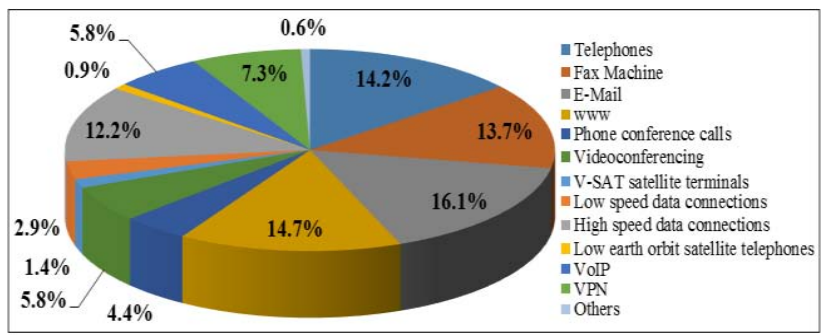

Figure 12: Communication Channel [1]

- IT Utilization Support

- The leaders have a strong drive for IT though most of organizations don't have enough IT education program for effective ICT technology utilization

- For example, when asked whether their leader "has a strong drive for IT", 75\% responded positively.

- However, when they were asked whether or not they "have an IT education program", only $20 \%$ said yes.

\section{Main Purpose of Projects [1]}

- Providing online public service is the most important purpose of the new government projects

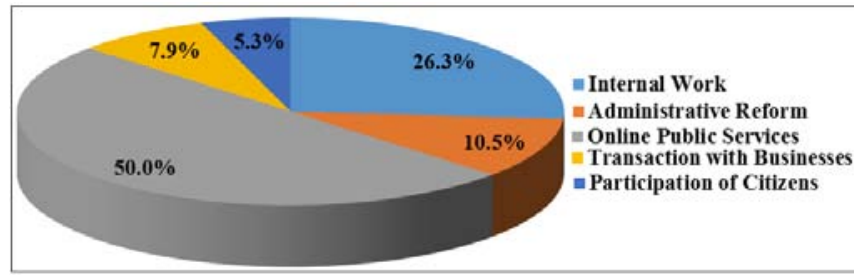

Figure 13: Main Purpose of Projects [1]

\section{Requirement of Citizen \& Business Enterprises}

\section{Overview [1]}

A questionnaire survey was conducted to seek out requirements of citizens and business executives. The survey results are based on the level of informatization of the nation, awareness of e-Government, requirements of eGovernment, and priority services that are necessary. Part of the survey results.

\section{General Information:}

\section{- Questionnaire Survey Results [1]}

In order to understand the current e-Government status of Sudan, a questionnaire survey was conducted on 80 citizens, 14 business executives, and 36 technical staffs.

The survey consisted of questions such as how respondents accessed information, what medium they used for internet connection, how often they received ICT training etc. Based on the results, the stakeholders' requirements for eGovernment were analyzed.

\section{- Access to Information [1]}

When asked what types of media they used to access information, both stakeholders chose Internet as primary

\section{Volume 6 Issue 1, January 2017 www.ijsr.net}




\section{International Journal of Science and Research (IJSR) \\ ISSN (Online): 2319-7064 \\ Index Copernicus Value (2015): 78.96 | Impact Factor (2015): 6.391}

source of access to information. For second source, citizens chose newspaper and business and enterprises chose mobile devices to receive information.

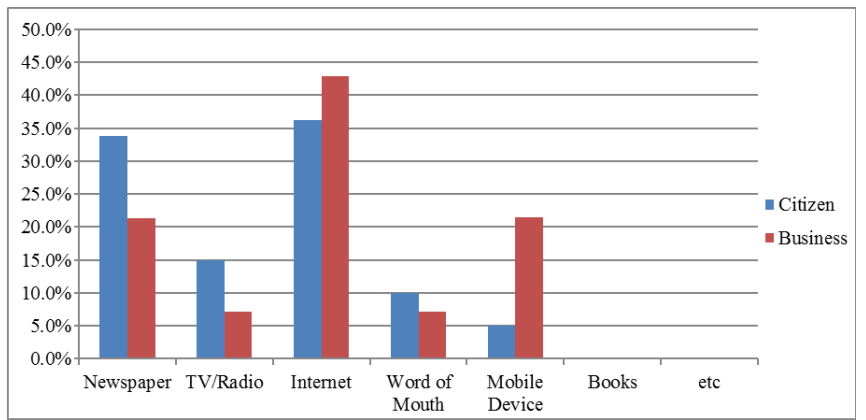

Figure 14: Access to Information [1]

\section{- Internet Connection [1]}

When asked how the respondents connected to the Internet, answers varied. The majority of citizens are using Broadband for means of internet connection. Business executives tend to use Cable as the primary means of internet connection and use broadband as their second means of connection, whereas many citizens are using modems as their second.

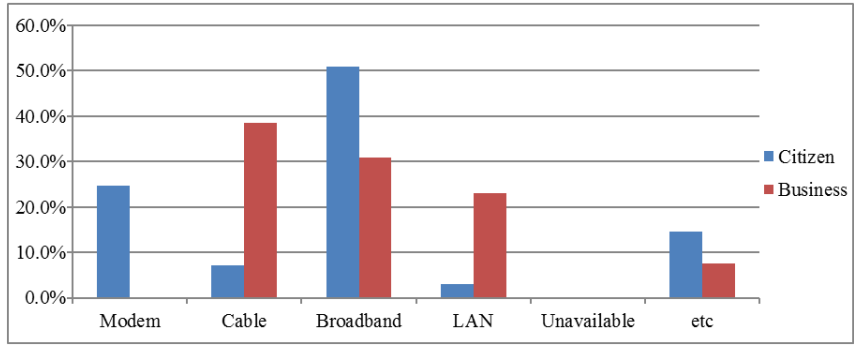

Figure 15: Means of Internet Connection [1]

\section{- ICT Education [1]}

Among the respondents, only $28.7 \%$ of citizens and $57.1 \%$ of business executives had received some form of ICT education.

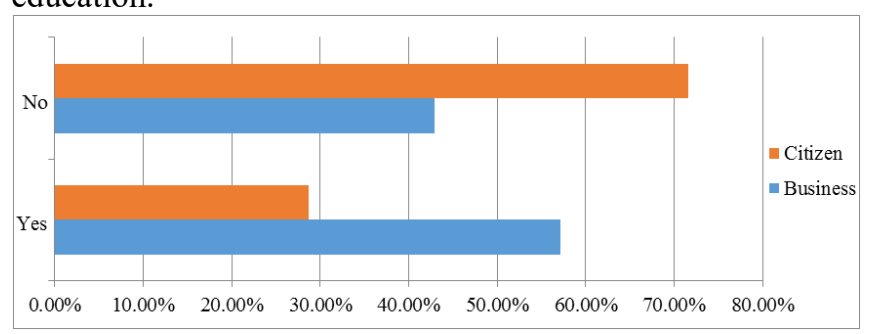

Figure 16: ICT Education [1]

When asked what type of ICT education they would like to receive, most citizens and many business executives chose programming such as Java, Visual Basic, PHP2, ASP, etc. Those citizens and business who chose others willing to learn on electronic accounting, maintenance and overall network of ICT.

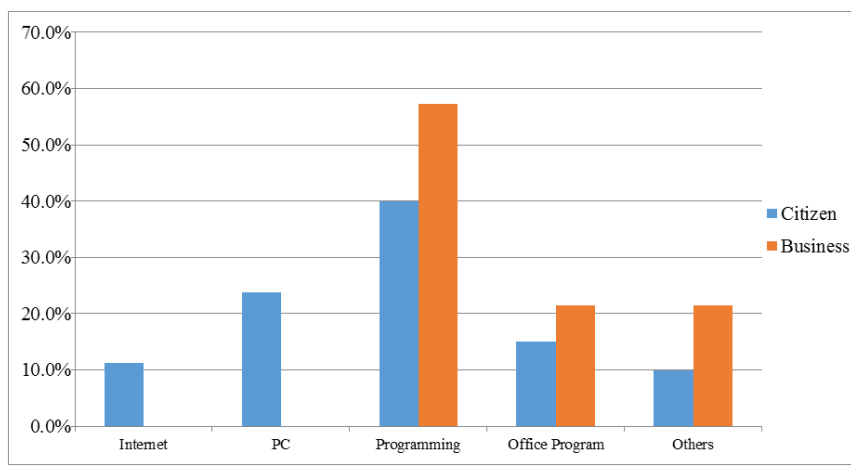

Figure 17: ICT Education Needs [1]

\section{- Civil Service}

In order to receive necessary civil services, citizens and business executives must visit the relevant government institutions or use telephone.

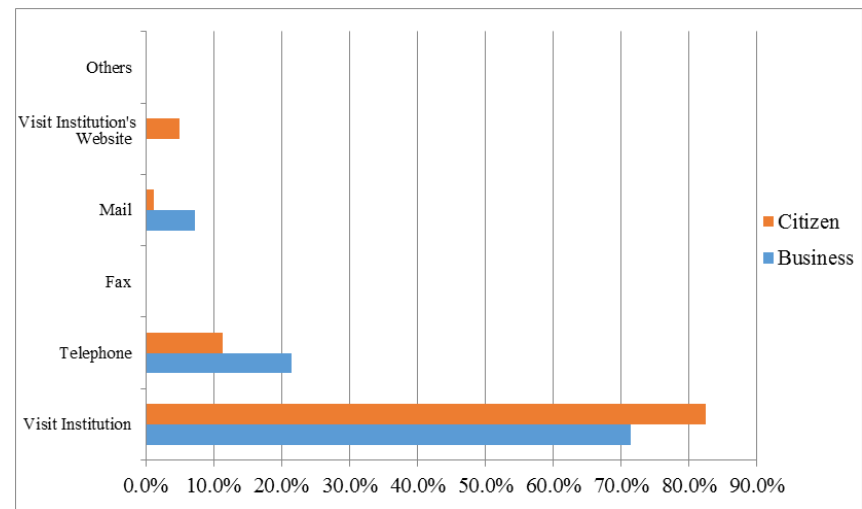

Figure 18: Civil Service Application [1]

- e-Government Service [1]

When asked whether or not they were aware of the ongoing national IT projects, average of $55.1 \%$ of citizens and $71.4 \%$ of business executives responded positively; others responded that they were not really aware of IT projects.

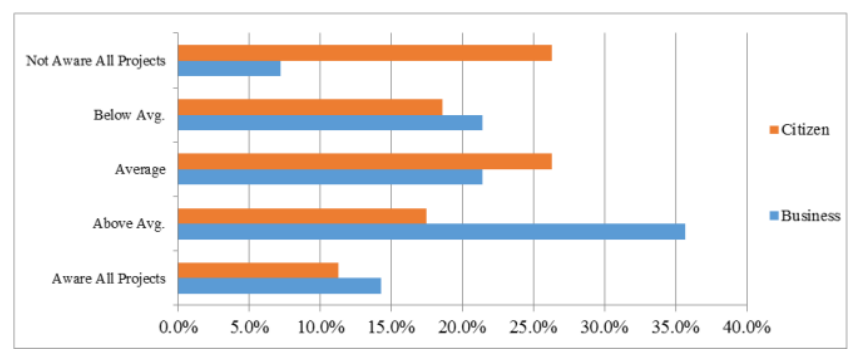

Figure 19: National IT Project Awareness [1]

When asked about what e-Government projects they considered as a national priority, citizens and business executives responded that expansion and improvement of telecommunication infrastructure as the top priority. 


\section{International Journal of Science and Research (IJSR) \\ ISSN (Online): 2319-7064}

Index Copernicus Value (2015): 78.96 | Impact Factor (2015): 6.391

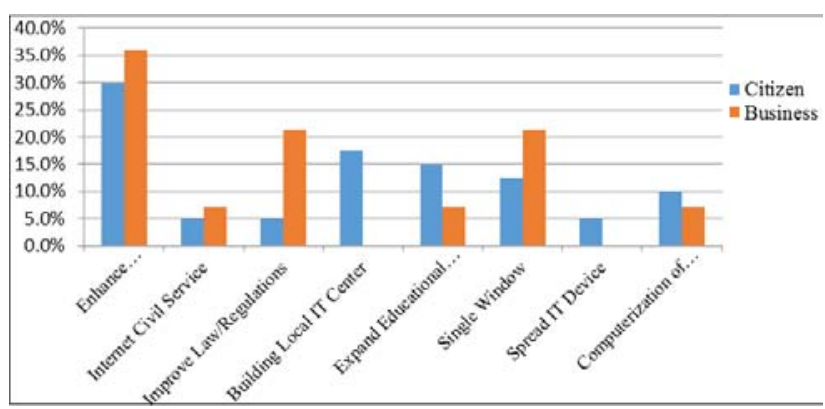

Figure 20: e-Government Priorities [1]

\section{NIAT Based Analysis}

General Overview: [1]

The e-Government Assessment Tool (NIAT) is a tool that was designed to provide a rapid assessment of a target country's informatization situation based on the experience and accumulated know-how of Korea's informatization development history. The NIAT primarily draws meaning from the insights of the target country's officers, since they have the best understanding of what needs to be done. The assessment is based on the presumption that it is primarily the government staff who knows the answer to the problem and not external specialists. By introducing Korea's informatization benchmark cases alongside identification of priorities, the lead time can be reduced by defining "quick win" projects.
Framework and Indicators [1]

The architecture used for the NIAT is based on the UNU Architecture for e-Government, and has been tailored to fit Korea's informatization development model (11 initiatives and 31 projects) and history. The framework is categorized into 4 groups, i) government, ii) citizens, iii) businesses, and iv) infrastructure. The services are further grouped into 15 "improvement themes", with 37 indicators derived from the improvements themes that have been defined

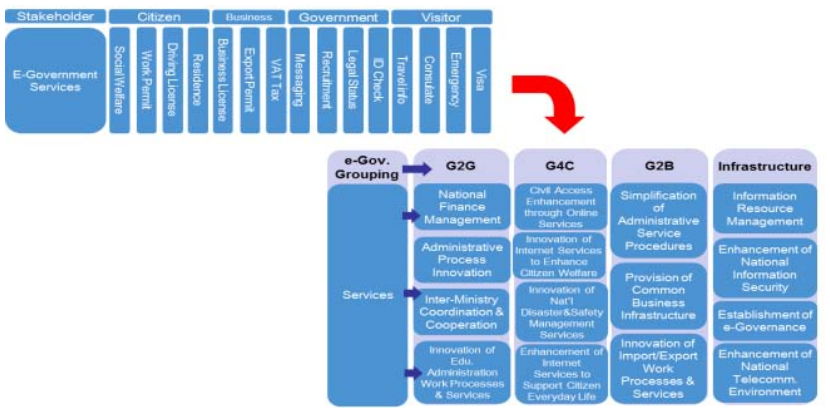

Figure 21: NIAT Framework [1]

The NIAT draws its indicators from widely recognized evaluations for e-Government maturity assessment such as the 'EU New e-Europe Statistical Handbook,' 'United Nations e-Government Survey,' and the 'Economist Information Unit(EIU) e-Readiness Index' among others.

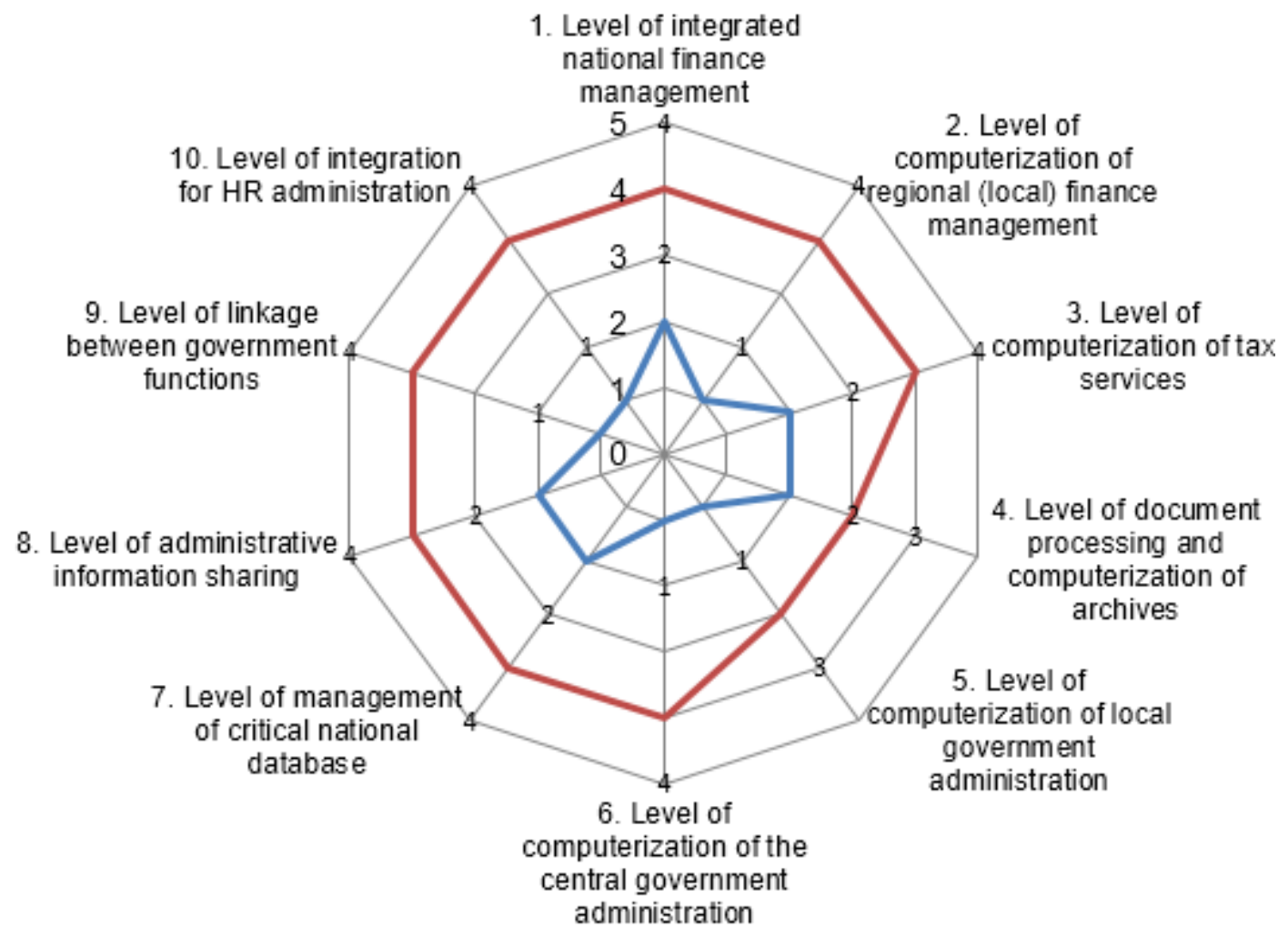

Figure 22: Results of Government GAP Analysis [1] 
International Journal of Science and Research (IJSR)

ISSN (Online): 2319-7064

Index Copernicus Value (2015): 78.96 | Impact Factor (2015): 6.391

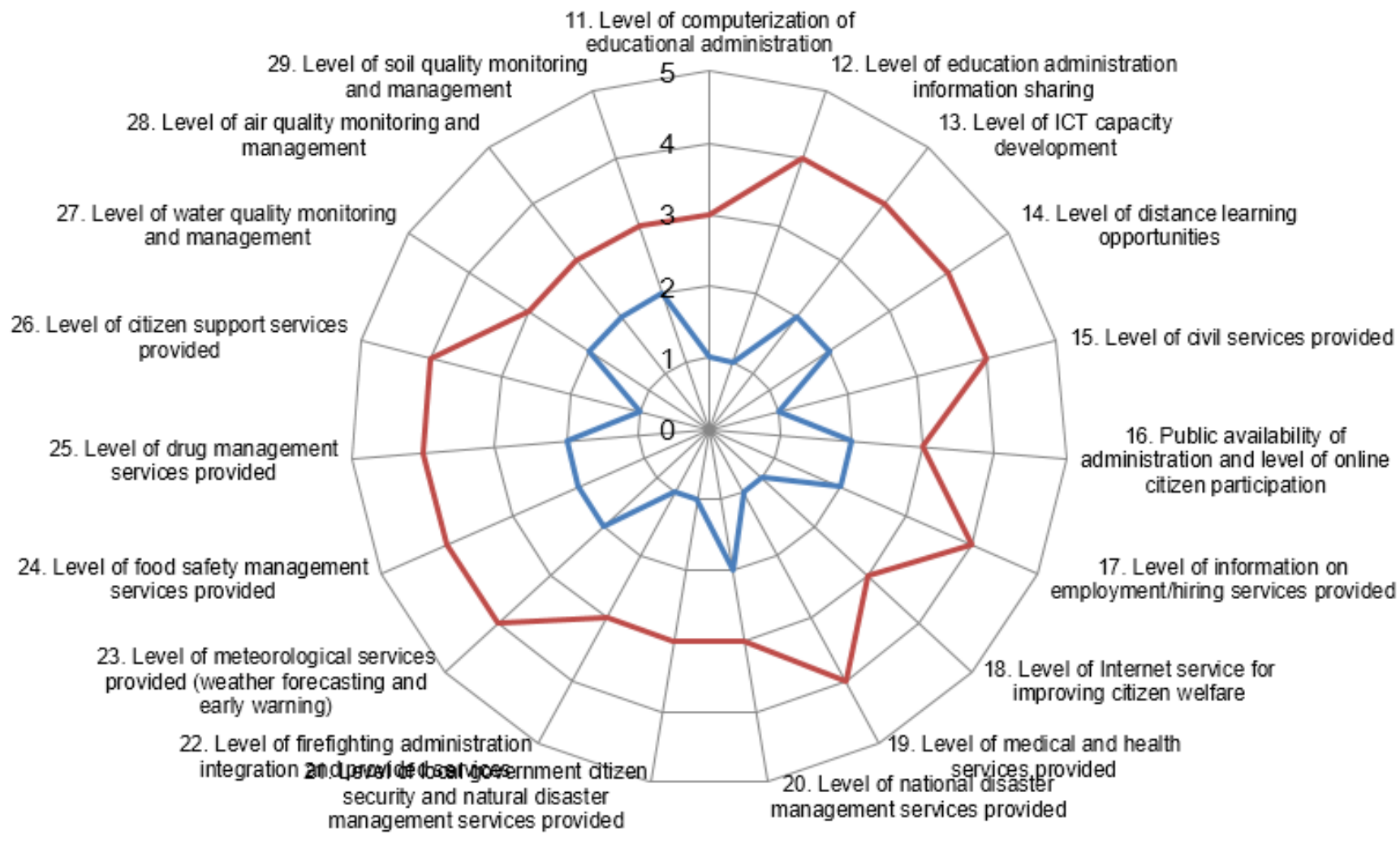

Figure 23: Results of Citizen \& Society GAP Analysis [1]

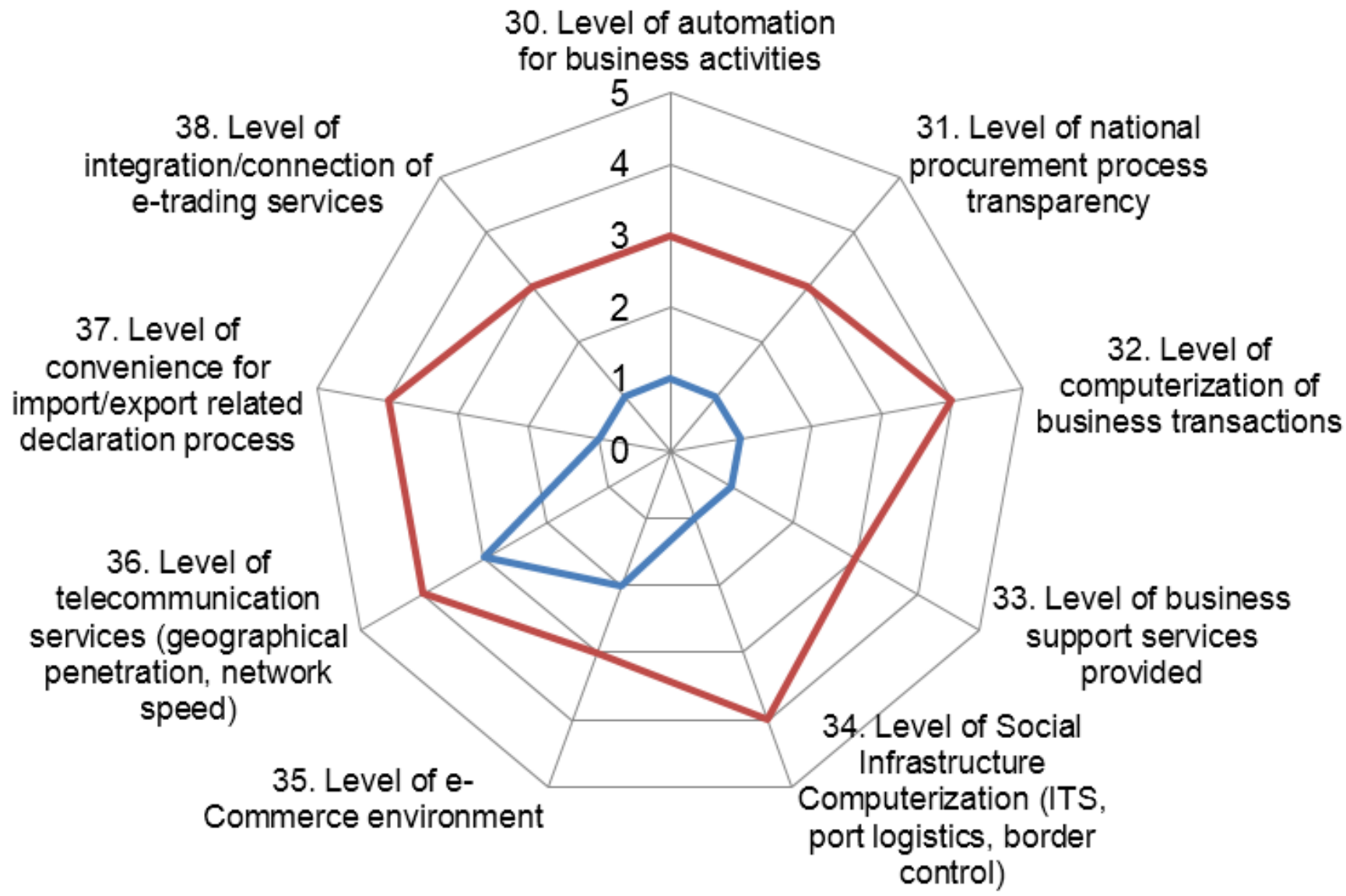

Figure 24: Results of Business GAP Analysis [1]

Volume 6 Issue 1, January 2017

www.ijsr.net

Licensed Under Creative Commons Attribution CC BY 


\section{International Journal of Science and Research (IJSR) \\ ISSN (Online): 2319-7064}

Index Copernicus Value (2015): 78.96 | Impact Factor (2015): 6.391

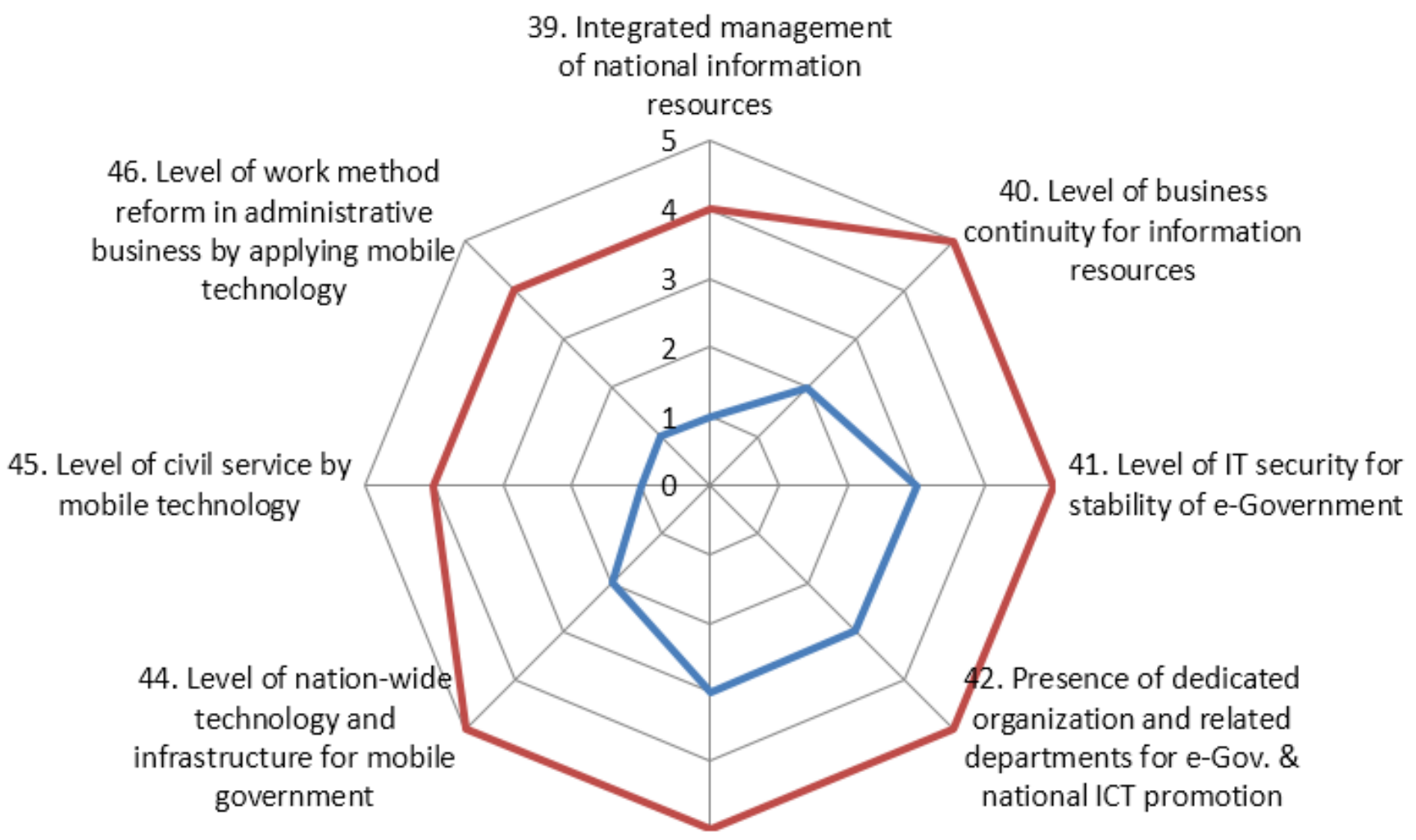

\section{Improvement and establishment of e- \\ Government/ICT laws and policies}

Figure 25: Results of IT Infrastructure GAP Analysis [1]

\section{Benchmarking Case Study [1]}

Overview:

Benchmarking is to assess the relative performance of the nation by certain standards. In this section, Republic of Korea will be benchmarked in regards to legal frameworks related to ICT, vision, strategies, e-Government development histories and initiatives. In addition, benchmarks provide a method of comparing the performance of various e-Government systems and services that currently available and will be implemented soon in country.

\section{1) 5.2 Korea's e-Government}

\subsubsection{Korea's Vision and Strategies}

\section{Vision and Goals (2008 Present)}

1) Vision: [1]

- The World's Best Digital Government Inside the People

- Vision 2030: Hopeful Korea in Harmony

2) Goals: [1]

- Offer Customer-Centric Customized Citizen Services: by integrating services with focus on citizens and businesses

- Accelerate System-Based Government Innovation: by building intelligent administration service system

- Enhance Preventive System for a Safer Society: by delivering real-time information network for public security
- Lay Groundwork for Sustainable Advancement of eGovernment: by enhancing infrastructure for eGovernment

3) Strategies: [1]

- Establish Governance Structure

- Innovate Process and Realign Systems

- Strengthen Performance Management System

- Enhance e-Government Human Resources

- Improve Global Leadership

Implementation Strategies

- Establish Governance Structure

- Innovate Process and Realign Systems

- Strengthen Performance Management System

- Enhance e-Government Human Resources

- Improve Global Leadership

\section{Critical Success Factors (CSF) [1]}

\section{GAP Analysis:}

The purpose of GAP analysis is to look at enabling technology, applications, systems and information technology processes that are available in a nation and which would be necessary for Government to realize its vision, strategic goals and objective for ICT. In carrying out the GAP analysis, the enabling environment such as ICT policies, available technology, level of standardization and compatibility of systems should be also factored in.

In this analysis, Republic of Korea and Sudan are each compared and sought gaps in terms of ICT status. 2014

\section{Volume 6 Issue 1, January 2017 www.ijsr.net}




\section{International Journal of Science and Research (IJSR) \\ ISSN (Online): 2319-7064}

Index Copernicus Value (2015): 78.96 | Impact Factor (2015): 6.391

Rankings of e-Government readiness index by UN are each compared, and each of the national ICT strategies is analyzed. In addition, ICT related legal framework, which supports e-Government, has been analyzed in each nation. Most importantly, three nations' e-Government services are analyzed in terms of $\mathrm{G} 2 \mathrm{G}, \mathrm{G} 4 \mathrm{C}, \mathrm{G} 2 \mathrm{~B}$ and Common Infrastructure.

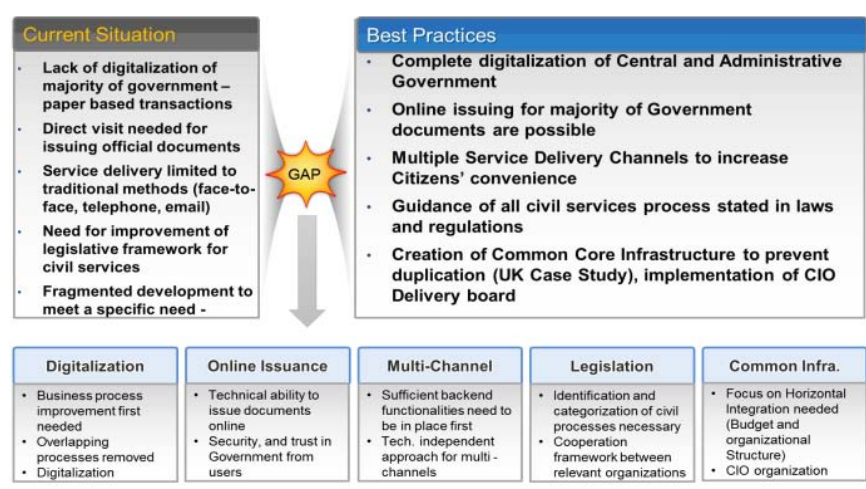

Figure 26: GAP Analysis with Best Practices [1]

Critical Information Requirement (CIR) [1]

CIRs are identified based on implications of PEST analysis, interview results from Government institutions, questionnaire surveys from citizens and business executives.

Table 3: Summary of CIRs [1]

\begin{tabular}{|c|c|}
\hline Classification & Requirements \\
\hline G2G & 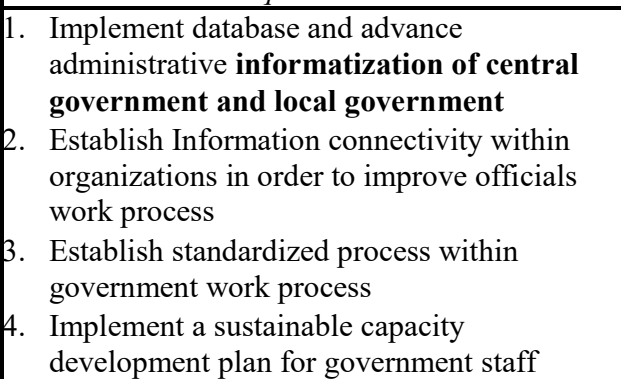 \\
\hline G4C & $\begin{array}{l}\text { 5. Focus on core online citizen services in } \\
\text { order to enhance citizen's life quality } \\
\text { 6. Implement e-Government service concerning } \\
\text { mobile environment } \\
\text { 7. Expand online civil communication services } \\
\text { for Government-Citizen interaction } \\
\text { 8. Develop citizens' general ICT capacities to } \\
\text { stimulate demand }\end{array}$ \\
\hline G4B & $\begin{array}{l}\text { 9. Implement a business service portal to } \\
\text { provide basic online business support } \\
\text { services, including possible support for } \\
\text { exports } \\
\text { 10. Implementation of secure platform for } \\
\text { online commerce transactions }\end{array}$ \\
\hline Infra & \begin{tabular}{|l|} 
ICT Point of View Legal System \\
\end{tabular} \\
\hline
\end{tabular}

Based on the identification of the following diagram illustrates the core directions for improvement for Sudan's e-Government.

\section{To-Be Model Development}

\subsection{Government Vision \& Mission [1]}

\section{Overview}

In the previous chapter, bibliographic study, surveys and interviews were conducted to review and analyze Sudan's current policy, ICT status and requirements for eGovernment. Benchmarking case study of Korea, and global ICT trends were analyzed to help establish the eGovernment of Sudan. Based on implications generated through the analysis, the critical success factors(CSF) and critical information requirement(CIR) are identified for establishment of e-Government in Sudan. Based on the CIR, directions for strategies were established which can be categorized into G4C, G2B, G2G and common infrastructure.

Being in the initial level of ICT (One-way communication), it is extremely important for Sudan to establish the eGovernment project which fits the environment of Sudan by utilizing lessons learned from the e-Government requirements, latest technologies and benchmarking case studies. These efforts will prepare the grounds for Sudan to leap forward in the global arena.

With these efforts, vision and mission for the establishment of e-Government as well as strategies to achieve such vision and mission were established. The vision and mission are set for the goal of e-Government project such as to share the value of the project with governments and citizens. This in turn, makes it possible to implement e-Government Mater Plan more effectively and efficiently.

NIPA's consulting team has derived and created a vision and mission statement from the previous chapters. The vision statement is established as an image of the future society that citizens imagine or hope it would be like, while the mission statement is established as a guide for formulating strategies of an important task that citizens are given to do.

NIC believes that the establishment of e-Government vision and mission statement are necessary for the development of ICT sector. NIC also realizes that the current government administration is willing to carry out and shared the budgets for ICT sectors for the development of e-Government.

\section{Vision [1]}

In general, a vision can be defined as a comprehensive concept for describing an image of the business success. In other words, it is the future image that Sudan would like to achieve in next five years through the e-Government. The following vision was drafted based on the results of the analysis of the previous sections. The general directions for improvement have been mapped to a specific S.U.D.A.N. strategy, while each e-Government domain has specific goals. Through this e-Government project, Sudan will become a regional information society leader based on strong digital foundations and services. 


\section{International Journal of Science and Research (IJSR) \\ ISSN (Online): 2319-7064}

Index Copernicus Value (2015): 78.96 | Impact Factor (2015): 6.391

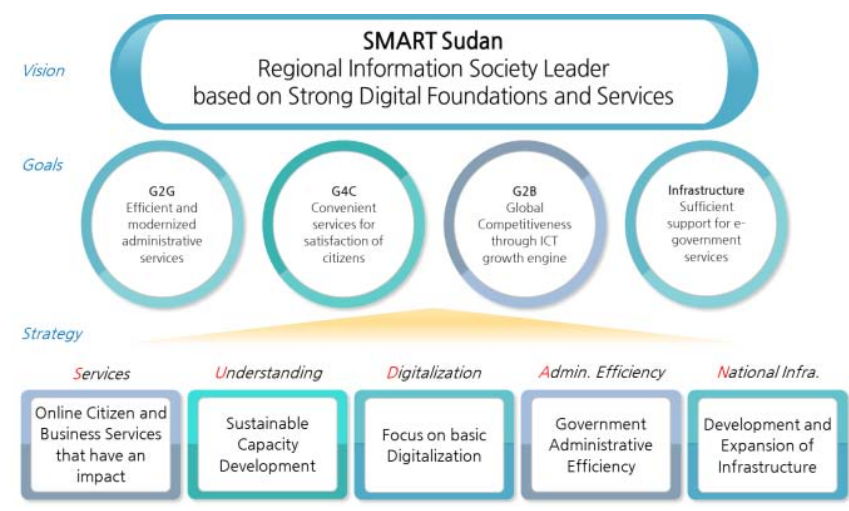

Figure 27: S.U.D.A.N. Strategy [1]

\subsection{Future Model}

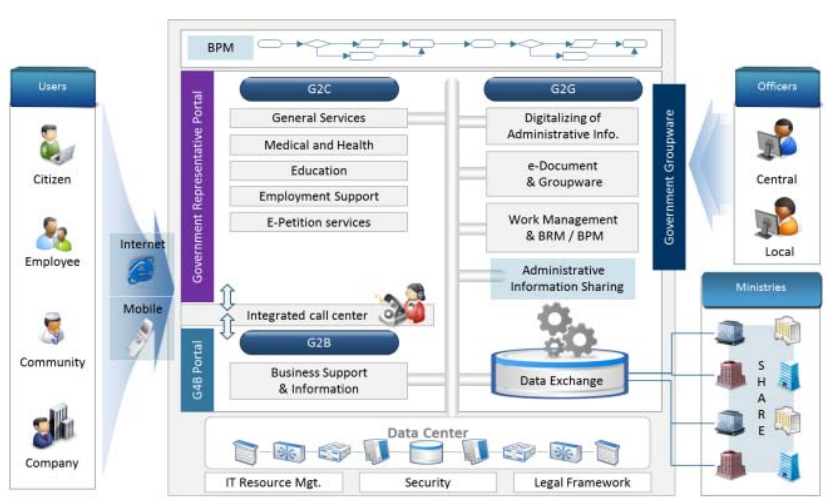

Figure 28: Sudan's e-Government To-Be Model [1]

Once the vision and mission for e-Government of Sudan are established, future model of Sudan's e-Government which provides a single-window for accessing one-stop civil services to citizens and a channel for private business entities to access necessary business information and services online, will be established. These activities can be done by active information sharing across the government institutions. Moreover, civil servants from the central and local governments will be able to log in to the government portal in order to do their work more efficiently. As for infrastructure, the government can achieve high-availability and security by integrating all the servers in one location.

The future image of Sudan's e-Government will also provide administrative services to its people through various channels, thereby improving the convenience of people. Also it will provide integrated and transparent administrative services for private business enterprises so that they can have greater competitiveness. All the work processes of agencies and departments are to be linked closely to one another, and enhancing work efficiency.

With these efforts, Government of Sudan will be able to realize a full knowledge-based society. [1]

\section{Strategy \& Initiatives}

\section{S.U.D.A.N. Strategy}

Based on the analysis of critical information requirements, a S.U.D.A.N. strategy has been developed focusing on 5 different areas.
- Services: Online services for citizens and businesses that have an impact

- Understanding: Sustainable Capacity Development

- Digitalization: Focus on core digitalization

- Administrative Efficiency: Improving the government's efficiency

- National Infrastructure: Development and expansion of infrastructure

\section{Services}

Priority projects will be evaluated and will be included in the roadmap for the establishment of e-Government in Sudan. Specific goals in establishing e-Government of Sudan are defined as follows:

a) G4C [1]

Efficient and modernized administrative services

- Implement database and advance administrative informatization of central government and local government

- Establish Information connectivity within organizations in order to improve officials work process

- Establish standardized process within government work process

- Implement a sustainable capacity development plan for government staff

b) G2B [1]

Convenient services for the satisfaction of the citizens

- Focus on core online citizen services in order to enhance citizen' s life quality

- Implement e-Government service concerning mobile environment

- Expand online civil communication services for Government-Citizen interaction

- Develop citizens' general ICT capacities to stimulate demand

c) G2G [1]

Regional and global competitiveness through ICTs as growth engine

- Implement a business service portal to provide basic online business support services, including possible support for exports

- Implementation of secure platform for online commerce transactions

d) Infrastructure [1]

Sufficient support for e-Government services

- Secure budget and expand ICT infrastructure to meet future demands

- Secure safety/security of digital information

- Efficient use of government ICT resources by sharing

- Prepare legal foundation to promote e-Government and ICT related projects - including government CIO positions

- Enhance the leadership and capacity of e-Government implementation organizations

- Secure a nation-wide agenda for ICT related projects 


\section{International Journal of Science and Research (IJSR) \\ ISSN (Online): 2319-7064 \\ Index Copernicus Value (2015): 78.96 | Impact Factor (2015): 6.391}

General Recommendations for the S.U.D.A.N. Strategy [1]

\begin{tabular}{|c|c|}
\hline Area & General Recommendations \\
\hline Services & $\begin{array}{l}\text { Identifying and developing "Killer" services that } \\
\text { are n Identifying and developing "Killer" services } \\
\text { that are needed by the majority of the citizens and } \\
\text { businesses that will provide real value to the users } \\
\text { Start of services that provide foundation for other } \\
\text { services and that can be scaled-up easily }\end{array}$ \\
\hline $\begin{array}{l}\text { Understanding } \\
\text { (Capacity } \\
\text { Development) }\end{array}$ & $\begin{array}{l}\text { Introduce a standard computer related curriculum } \\
\text { for secondary education and above } \\
\text { Implement an ICT training center within the } \\
\text { Government as a organization to ensure the ICT } \\
\text { capacity within the government of Sudan and } \\
\text { implement government training (Training of } \\
\text { Trainers) } \\
\text { Connect with other international and regional } \\
\text { training opportunities for continued development } \\
\text { (including Korea) }\end{array}$ \\
\hline Digitalization & $\begin{array}{l}\text { Implement process re-engineering before } \\
\text { digitalization to make sure the digitalization is } \\
\text { done correctly. This includes elimination of } \\
\text { unnecessary and redundant processes which may } \\
\text { have to supported by revisions in the legal } \\
\text { framework } \\
\text { Make sure to include plans for future } \\
\text { digitalization needs as well (digitalization is a } \\
\text { continuous process) }\end{array}$ \\
\hline $\begin{array}{l}\text { Administrative } \\
\text { Efficiency }\end{array}$ & $\begin{array}{l}\text { First priority is for development of strong } \\
\text { foundation } \rightarrow \text { government groupware } \\
\text { Expansion into an integrated administrative } \\
\text { management system within the government that } \\
\text { integrates all of the functions (integrated work } \\
\text { management system) }\end{array}$ \\
\hline $\begin{array}{c}\text { National } \\
\text { Infrastructure }\end{array}$ & $\begin{array}{l}\text { Development of a Government Integrated Data } \\
\text { Center (GIDC) to ensure concentration of } \\
\text { expertise } \\
\text { Development of a e-Government framework for } \\
\text { Sudan to lower the entry barrier for development } \\
\text { Embargo Response: Coherent and standardized } \\
\text { approach for 3rd party procurement - not } \\
\text { individual purchases - additional preparation for } \\
\text { embargo end - develop ties in advance with } \\
\text { vendors (based on identification of needs) }\end{array}$ \\
\hline
\end{tabular}

\section{Implementation Strategy}

In the previous chapter, priority projects which should be executed to establish Sudan's e-Government were identified, and these projects are incorporated into e-Government road map in the order of their priorities.

To implement predefined e-Government projects, more details of functions and specific requirements of projects must be defined. Therefore, to facilitate the establishment of Sudan's e-Government, Sudan's e-Government and Transition to Smart Government Roadmap from 2016 to 2020 will be identified in this chapter. Details of functions such as budget, required manpower and time which would take to implement are included.

\section{1.e-Government Road Map [1]}

\section{Overview}

In Chapter II, the ICT status of Sudan, benchmarking case studies, and ICT trends were analyzed. Based on this analysis, the vision, mission and strategies for Sudan to realize e-Government were presented in Chapter III with projects to be conducted. As previously mentioned, Sudan's e-Government master plan has set the goals to be achieved in four years starting from 2016. Thus, project schedule and action plans must be drawn out to meet this given time frame.

In order to set realistic and specific goals, development model of Korea was taken as reference, and the eGovernment development model that fits the Sudan situation was created. After developing the e-Government model for Sudan, the target level for 2020 was determined and conditions needed to achieve such level were defined.

While all the projects defined in the previous chapter need to be executed, it is realistically difficult to implement them all at the same time due to insufficient budget and system, lack of technical workforce, insufficient awareness among people and poor infrastructure. Thus, prominent figures from all the sectors of Sudan and the consulting team from NIPA Korea has evaluated the feasibility of these projects, such as its importance and possibilities, and determined their priorities. The order of priority is reflected in the roadmap which Sudan has to implement to achieve the target level in four years. Other essential issue such as securing budgets are being prepared separately.

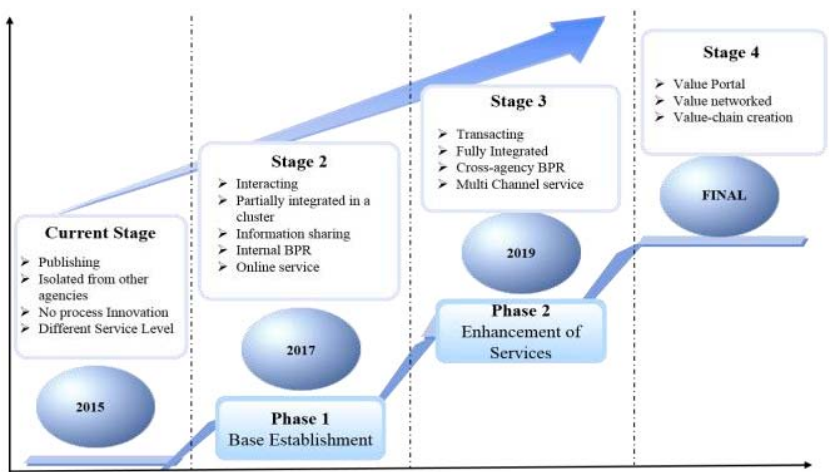

Figure 28: Goal of Sudan's e-Government [1]

\section{E-Government Roadmap [1]}

The results from the assessment above are summarized into the roadmap below according to each stage, so that it can help Sudan establish the e-Government in a realistic and efficient manner and jump to the $2^{\text {nd }}$ stage of e-Government model by 2017 .

First of all, goals and strategies for each sector of eGovernment project and projects to achieve them are as follows: 


\section{International Journal of Science and Research (IJSR) \\ ISSN (Online): 2319-7064}

Index Copernicus Value (2015): 78.96 | Impact Factor (2015): 6.391

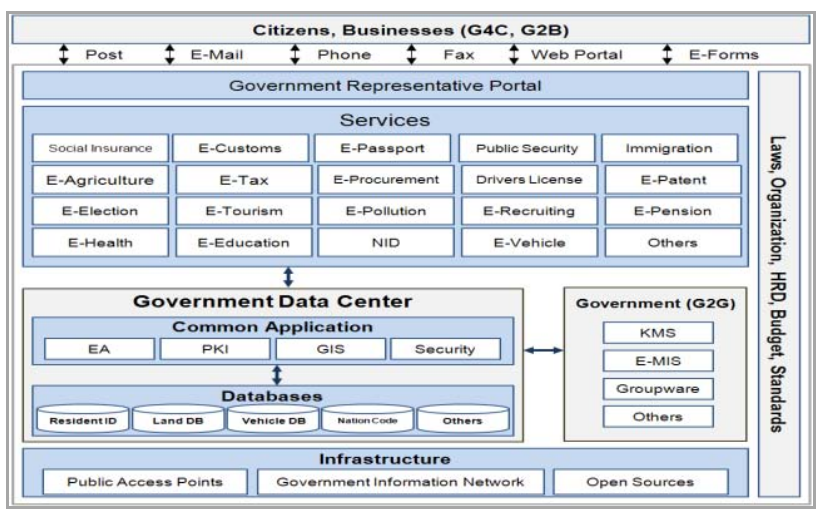

Figure 29: Roadmap of e-Government [1]

Its priorities and schedule are based on the five-year plan as is shown below:

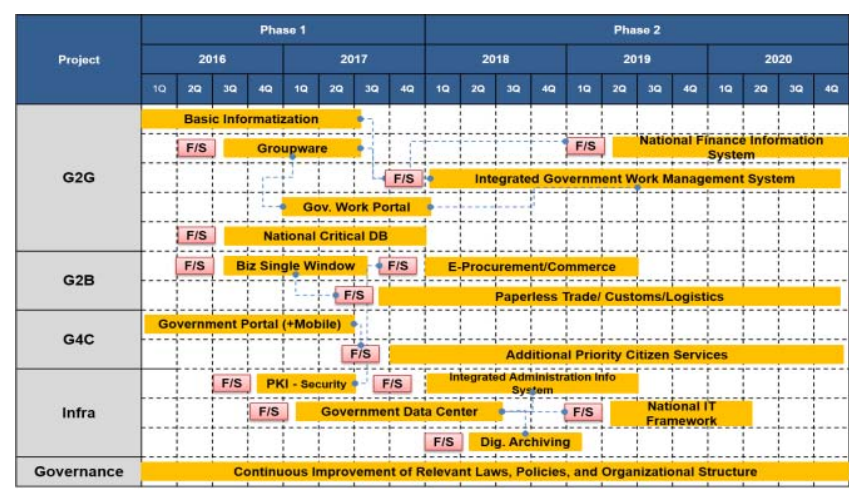

Figure 30: Timeline for the Roadmap of e-Government [1]

Following detailed roadmap is drawn up with detailed phases for each project in the $\mathrm{G} 4 \mathrm{C}, \mathrm{G} 2 \mathrm{~B}, \mathrm{G} 2 \mathrm{G}$, and Infrastructure sectors, according to the entire project schedule above. Governance is an essential dimension to eGovernment, and activities should continuously be developed to absorb and manage the change required

In order to create an environment where the e-Government project can be executed smoothly, Sudan needs to make the following preparations as identified in the benchmarking studies.

\section{Organization}

\section{Organization Model}

In Chapter 2, based on status review and benchmarking studies of countries with advanced ICT organization, Sudan should first create organizing bodies that can effectively build the e-Government of Sudan. It will require establishment of e-Government presidential committee under the supervision of the head of state. Also, it will require establishment of a CIO Council which will consist of CIO's from each of the ministries. NIC's role will be to plan, communicate and integrate the e-Government strategy

The e-Government presidential committee can be the expanded organization of the Ministry of Information, Communication, and Technology (MoICT). This committee should establish the vision for Sudan's e-Government, establish, execute, and evaluate national ICT policy in order to prevent redundant investment and conduct national informatization projects in an efficient and consistent manner.

The role of executing e-Government projects within public institutions should be clearly defined to undertake full responsibility by the designated CIO. The ICT organization will be composed of the following. A government-wide reorganization might be reconsidered for efficiency and effectiveness.

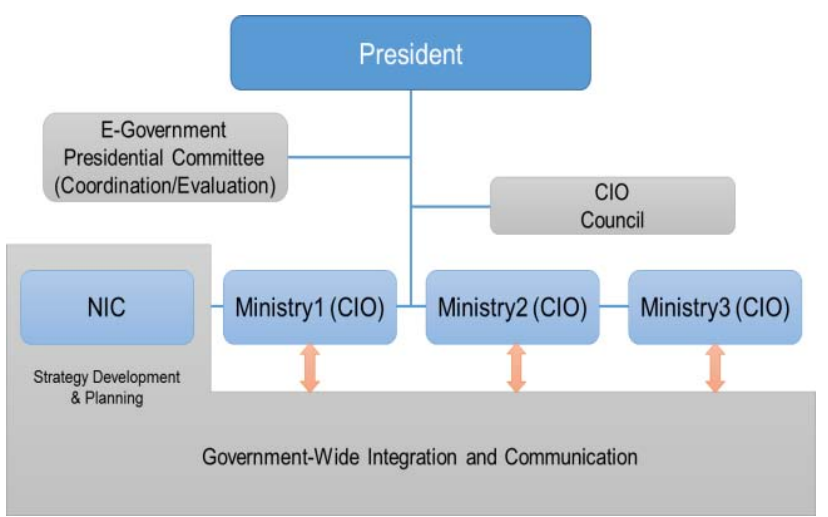

Figure 3: Organization To-Be Structure [1]

\section{Benefit [1]}

The e-Government Standard Framework increases development productivity and component reusability among application systems by providing a standardized infrastructure, increases the interoperability and promotes the standardization of application SWs through the interface standards.

- Increase in development productivity: Minimizes redundant developments by providing common essential functions and allows developers to concentrate on the business logic by defining an infrastructure.

- Increase in the reusability of e-Government application systems: Increase the standardization of the development framework allows components already developed on the e-Government Standard Framework to be reused in other application systems.

- Increase in the interoperability of the e-Government systems: Increase the interoperability of application systems by using standard inter-system integration interface.

- Standardization of e-Government application systems: Promotes the standardization of the program code by providing the standardized development infrastructure for presentation, business logic processing and data processing.

- Promotion of open source SW use: Promotes the developer's use of open source SWs by defining open source based standard framework.

- Improvements in the competitiveness of SM-sized SW vendors: Strengthens the competitiveness of SM-sized SW vendors by sharing the e-Government Standard Framework and increasing development manpower skillful in developing on the framework

\section{Action Plan [1]}

\section{Overview}

According to Sudan's vision and mission statements of eGovernment, the following projects are identified as priority

\section{Volume 6 Issue 1, January 2017 www.ijsr.net}




\section{International Journal of Science and Research (IJSR) \\ ISSN (Online): 2319-7064 \\ Index Copernicus Value (2015): 78.96 | Impact Factor (2015): 6.391}

projects in order to establish e-Government in Sudan. The 25 priority projects are identified based on portfolio analysis in consideration of importance, and feasibility. Among the projects, 13 projects are selected for Phase I and Phase II according to the Table below. This chapter is to identify budget and scope of each project.

Table 32: 25 Priority Project Overview [1]

\begin{tabular}{|c|c|c|c|c|}
\hline Phase & No. & Project & Definition & Service Type \\
\hline \multirow{6}{*}{$\begin{array}{c}\text { Phase } 1 \\
\text { Base } \\
\text { Establishment }\end{array}$} & 1 & $\begin{array}{l}\text { Groupware (e-Document, e-Approval, } \\
\text { Knowledge Management System) }\end{array}$ & $\begin{array}{l}\text { Users create and share documents through designated } \\
\text { work portal and connection with record management } \\
\text { system }\end{array}$ & G2G \\
\hline & 2 & Government Representative Portal & $\begin{array}{l}\text { All government services such as e-Application and e- } \\
\text { Issuance can be accessed through a single window }\end{array}$ & $\mathrm{G} 4 \mathrm{C}$ \\
\hline & 3 & National Critical Database & $\begin{array}{l}\text { Informatizing citizen's information from birth to } \\
\text { death, and resident life }\end{array}$ & G2G \\
\hline & 4 & Single Window for Online Business & $\begin{array}{l}\text { A single-window based on integrated services which } \\
\text { are necessary for business enterprises }\end{array}$ & G2B \\
\hline & 5 & PKI & $\begin{array}{l}\text { An electronic certificate of qualification for } \\
\text { individuals to access information }\end{array}$ & Infrastructure \\
\hline & 6 & Government Data Center & $\begin{array}{l}\text { To ensure the safety of national information and to } \\
\text { provide integrated services }\end{array}$ & Infrastructure \\
\hline \multirow{7}{*}{\begin{tabular}{c|} 
Phase 2 \\
Enhancement of \\
Service
\end{tabular}} & 7 & $\begin{array}{c}\text { Integrated Administration information } \\
\text { system }\end{array}$ & $\begin{array}{l}\text { Allow integrated management of backend } \\
\text { administration for local governments }\end{array}$ & G2G \\
\hline & 8 & $\begin{array}{l}\text { National Finance Information System } \\
\text { (NAFIS) }\end{array}$ & $\begin{array}{l}\text { A system which assists budget related work from } \\
\text { national budget execution to settlement }\end{array}$ & G2G \\
\hline & 9 & Digital Archiving & $\begin{array}{l}\text { A system which digitalizes and stores data and } \\
\text { information }\end{array}$ & G2G \\
\hline & 10 & Electronic Procurement System & $\begin{array}{l}\text { Cost reduction by digitizing purchasing procedures of } \\
\text { all institutions }\end{array}$ & G2B \\
\hline & 11 & $\begin{array}{l}\text { Administration Information Sharing } \\
\text { Center }\end{array}$ & $\begin{array}{l}\text { Sharing administrative information across the } \\
\text { government institutions and helps citizen's visit to } \\
\text { gov. office }\end{array}$ & Infrastructure \\
\hline & 12 & National IT Standard Framework & $\begin{array}{l}\text { Maximizes the development productivity, assures the } \\
\text { quality and minimizes the risk factors }\end{array}$ & Infrastructure \\
\hline & 13 & $\begin{array}{l}\text { Integrated Government Work } \\
\text { Management System }\end{array}$ & $\begin{array}{l}\text { Allows administrative work to become systematic } \\
\text { process-based by managing the accumulated } \\
\text { knowledge assets from previous experiences }\end{array}$ & G2G \\
\hline
\end{tabular}

\section{Example of Project:}

\section{Government Information Data Center [1]}

\section{Overview}

National data can be managed in order to ensure the safety of national information and to provide integrated services to the citizens

\section{Conceptual Image}

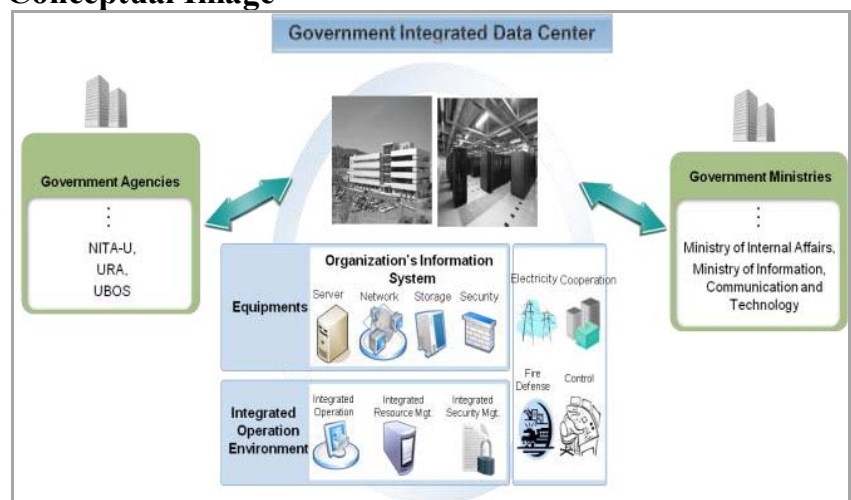

Figure 33: Government Integrated Data Center [1]
Functions [1]

- Integrated operation: Offers interoperability by information sharing and supports sustainability of government's core services

- Integrated resource: Information are shared and managed efficiently via communicating among government institutions

- Integrated security: Integrated security facilities are implemented for information protection and management

\section{Schedules}

Table 34: Schedule - Government Integrated Data Center

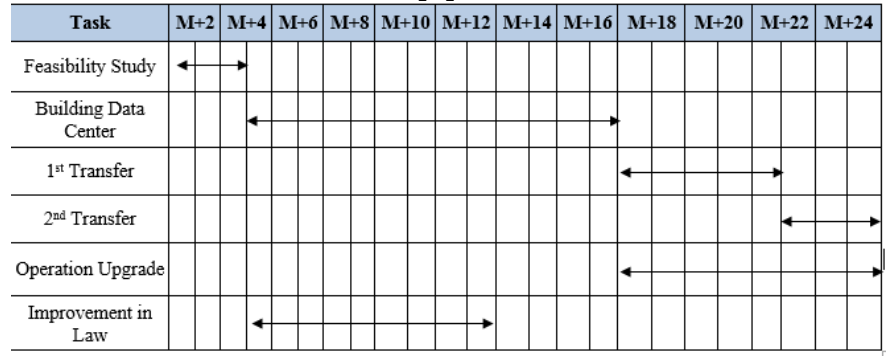




\section{Budgets}

Table 35: Expense - Government Integrated Data Center [1]

\begin{tabular}{|c|c|c|}
\hline Types & Calculation & Amount (USD) \\
\hline Consulting & Consultant for ISP: $176 \mathrm{M} / \mathrm{M}$ & $2,288,000$ \\
\hline Development & Develeloper: 1716 M/M & $10,296,000$ \\
\hline $\begin{array}{c}\text { Infrastructure } \\
\text { [Hardware and Software] }\end{array}$ & $\begin{array}{c}\text { Server, Network, Storage, Solutions } \\
\text { (SMS, NMS, FMS, EMS, etc.) }\end{array}$ & $11,441,000$ \\
\hline \multicolumn{2}{|c|}{ Total } & $24,025,000$ \\
\hline
\end{tabular}

Expected Benefits [1]

- Efficient allocation of resources and maximize utilization of resources

- Reduce downtime and cost through integration

- Increase interoperability \& efficiency of systems through standardization

- A comprehensive management of condition, rules, guidelines, and etc.

\section{References}

[1] Sudan e-Government Master Plan and Transition to Smart Government 2016-2020 NIPA Report.

[2] https://publicadministration.un.org/egovkb/portals/egov $\mathrm{kb} /$ documents/un/2014-survey/e-gov_complete_survey2014.pdf

[3] www.dbde.org

[4] www.worldbank.org

[5] www.unpan.org

[6] www.oecd.org

[7] NIPA website (http://www.nipa.kr/eng/main.it)

[8] National Information Center - Sudan (nic.gov.sd or esudan.gov.sd) 